\title{
Review of the Recovery Strategies of Pakistan: Dealing Tourism Wreaked with Terrorism
}

\author{
Muhammad Fahad Khan* \\ Hospitality and Tourism Management, MSc, Independent Researcher, 25000 Peshawar, Pakistan
}

*Corresponding Author: Muhammad Fahad Khan, Hospitality and Tourism Management, MSc, Independent Researcher, 25000 Peshawar, Pakistan

\begin{abstract}
Tourism is a fragile and vulnerable industry that could suffer tremendously with any crisis. One of the major challenges faced by the tourism industry in the present day is Terrorism. With a special focus on Pakistan, the fourth most terrorism inflicted country in the world, this research appraises previous recovery approaches adopted in response to political flux or terrorism and then apply its implications to Pakistan tourism industry. There are several crisis management models available, however most of those models are too general and difficult to put into operation. Finding indicates that tourism industry cannot resolve the issue of violence, but it is to a certain extent an administration level matter and government of Pakistan will have to take actions to find a solution for this problem. Pakistan's current response to the crisis is also evaluated in the present study. Negative image has contributed its part in the drastic fall of tourism industry of Pakistan. Therefore, the role of media in creating an image of Pakistan in the minds of tourists and its careful manipulation by terrorists is thoroughly discussed.
\end{abstract}

Keywords: Tourism, Terrorism, Pakistan, recovery strategies, Crisis Management

\section{INTRODUCTION}

Tourism is a fragile industry that can suffer tremendously from changes, especially the ones wherein security and safety of the tourist is at risk. One such emerging threat to tourism in the last decade is terrorism. It is defined as the use of violence by individuals or groups outside legitimate structures and processes, with the sole purpose of achieving desired results that are generally political in nature(Henderson et al. 2010). One of the major countries, severely affected with tourism inflicted with terrorism is Pakistan. With 1,933 attacks killing 2,345 people, Pakistan ranks fourth in Global Terrorism Index, preceded by Iraq, Afghanistan and Nigeria (Global Terrorism Index Report 2016). The 9/11 event and the "war on terror" have proved to be fatal for the tourism sector of Pakistan, especially in the areas where international tourism has already played a prominent role in regional development. There have been increasing reports in the last decade on terrorism wreaked disasters in Pakistan, including the recent twin blasts in Parachinar, killing 75 people and leaving 150 people wounded (23 June 2017).

Tourism plays a tremendous role in economic growth of any country. Interestingly, Hye and Khan examined the tourism led growth in Pakistan by using annual time series data from 1971 to 2008 and found out the long-run relationship between income from tourism and economic growth and explained that income from tourism has led economic growth in Pakistan except in the years 2006, 2007, and 2008, due to earthquake and war against terrorism in northern areas (Adnan Hye and Ali Khan 2013). Unfortunately, terrorism may cause political instability(Seddighi, Theocharous, and Nuttall 2002), resulting in less number of arrivals in some tourist destinations, as seen in case of US after the terrorist attack on 9/11(Cohen, Prayag, and Moital 2014; Kozak, Crotts, and Law 2007). With respect to political instability, the emergence of individuals or autonomous groups aligned to the aims of alQaeda continues to threaten the developed world, especially as insurgents can operate in instable countries such as Pakistan and Yemen.

With the increasing threat of terrorism, it is important for a tourist destination to adopt a recovery strategy to limit any further damage(Henderson 2003; Richter 1999). Interestingly, constant terrorism attacks have a more severe impact on the tourism destination that have a more lasting effect, 
eventually leading to a complete disintegration of a tourism destination(Pizam and Fleischer 2002).Therefore, rebranding destination by different exhibitions, tourism attractions and sport competitions become a crucial factor in improving the overall image of any destination (Avraham 2013; Shaw et al. 2007). However, the impact of terrorist activity is directly proportional to the media coverage of those events and hence can lead to a long term crisis for the tourism destination(Sönmez and Graefe 1998) due to immediate public attention through considerable media coverage. There have been an increasing number of reports that mention the crucial role of media in terrorist traits (Kapuściński and Richards 2016) and its negative influence on tourism industry (Thomas 2012).

With a special focus on Pakistan, the present study investigates different recovery strategies applied to deal with the issue of tourism inflicted with terrorism. The study also mentions the limitations with respect to each strategy, thereby opening a flank for discussion in improving the policies to boost the tourism and improvement of the overall image of the country.

\section{RECOVERY STRATEgies OF PAKISTAN}

Pakistan has no dearth of destinations of tourism attraction. Interestingly, tourism is the sole means of earning a livelihood in some regions. However, since the last decade of extreme terrorism, the Pakistan tourism industry has been severely impinged. Unfortunately, due to the involvement of high risks and increment in level of insecurity, international tourists are repelled. Terrorists recognise the impact of attack on foreign tourist, and thereby aim to create a sense of fear among the tourists(Aschauer 2010). With this regard, the Government of Pakistan has been on the front-line ally of United nations 'war on terror' and many al Qaeda militants are either killed or handed to United States. Pakistan's response to Taliban is also been harsh and few military operations in Swat and Bajour agency have been successful. Many Taliban commanders have been killed, and some are behind bars. Additionally, Pakistan's Prime Minister approval to the removal of the ban on executions in terrorism cases, in response to the terrorist attacks on school children in Peshawar was a commendable step towards managing this threat.

According to Faulkner et al, the effectiveness of any tourism industry in dealing with crisis is directly proportional to what degree the industry is prepared for recovery(Faulkner 2001). The threat of terrorism to the stability of Pakistan has clearly led the government to take strong actions against them. Even though terrorism related crisis on tourism industry has effects on all destinations, the period of recovery can vary for each destination. Therefore, frequent terrorism incidents have a more lasting effect that eventually can lead to a complete collapse of a tourism destination(Dean 2002). Based on the frequency of terrorism incidents, Pakistan stands at position 8 in list of most dangerous countries in the world (The Nation, 2014) and fourth in Global Terrorism Index, preceding Iraq, Afghanistan and Nigeria (Global Terrorism Index 2016). However, the effect of frequent terrorist attacks on foreign tourists is significantly higher than the domestic tourists (Dean 2002). In this perspective, effective decision making becomes crucial to enable accurate judgments in a case of any crisis(Tichy and Bennis 2007). Consequently, Pakistan tourism industry needs to establish a solid foundation, a "good tourism policy" and "full government backing" in order to recover the negative image caused by terrorism (The diplomat, 2013).

Another insight was provided by Taylor et al, that suggested assortment of a different target market in the time of crisis so as to attract tourists in the critical times as there are potential tourists that are less afraid of terrorism threat or they are not aware of the crisis(Holloway and Taylor 2006).Furthermore, the image of a country is not same for all markets, therefore, it is required to communicate different message to a different target market, As a result, a feature of a place that might be negative for one audience could be considered positive by a different audience(Lindberg, Hansen, and Eide 2014). For instance, Pakistan Cricket Board was struggling to attract any international cricket team to their home grounds due of the attacks on the Sri Lankan team bus at Lahore in 2009, along with the consequent threats of terrorist attacks. Pakistan had to play all their home games in the United Arab Emirates because of security concerns, losing out on significant revenues. However, in December 2014, Kenya visited Pakistan. According to Pakistan Cricket Board (PCB), everything was ensured to not repeat the 2009 incident. They coordinated closely with the police and government to provide top security to the visitors, thereby restoring the faith of people in their home grounds and consecutive inflow of tourist to attend the sport matches. Hence, hosting a sport event diverted the media attention and focused on a specific location for a brief period. Adopting this strategy allowed tourist destination to 
improve an unsafe image and created positive news(Avraham 2013). Similar examples were seen in Egypt that overcame struggles with frequent terror attacks by shifting the attention of the world through hosting special events for international tourists and by promoting visits to its ancient archaeological sites (Wahab 1996).

In order to put an end to the violence, several negotiations had been ensured between the Pakistani government and the terror hub Taliban, however the outcomes of such meetings were generally futile. The government began a mission in the militant hub of North Waziristan, the last remaining tribal area where the military had not launched an operation. According to the Pakistan army officials, more than 1,000 militants were killed in the operation. Similar large-scale military operations were then launched. Unfortunately, in the wake of such military incursions in Swat (2009) and the Federally Administered Tribal Areas (2010), thousands of people have been forced to flee the war zones. It was not only hard for residents of that area to be displaced within their own country but also for the government of Pakistan to provide food and shelter for those internally displaced people. Pakistan's insurgencies combined with similar activity by the government of Afghanistan has put the Taliban on both sides of the border under unprecedented pressure (Times, 2014). Contrarily, Cohen et al argued that Pakistan military needed to reduce its reliance on conventional war-fighting capabilities in favour of population centric COIN operations (Cohen et al. 2009). At the higher levels, Pakistan army officers insist that there is no urgent need to look for alternatives beyond relying on well trained infantry soldiers to fight insurgent militants, a perception belied by the army's own experiences. Unfortunately, conventional military tactics are not suited against the militants, who can take advantage of their local knowledge of the mountainous terrain and meld into the local population(Cohen et al. 2009). At its core, COIN is a concept that proceeds along four lines of operation, military engagement, the provision of essential services to affected populations, training and equipping local law enforcement and administrative officers, and economic and social development (Davidson 2009). The difficulty faced for counter terrorism is the ill-equipped police force of Pakistan. Police infrastructure in Pakistan is one of the most poorly managed organizations in the state. Pakistan police is often described as ill-equipped, poorly trained, deeply politicized and chronically corrupt (David Rohde, New York Times, 2002). On the other hand, Taliban militants are highly train and motivated, making police force of Pakistan most vulnerable to their attacks.

Tourism has a major responsibility to ensure that policy, plans and partnerships are in place across the tourism sector through the support the active role of the police in the event of a crisis. Interestingly, a comparative study of role of police force in counterinsurgency campaigns in Malay and Cyprus concludes that nearly all major counterinsurgency campaigns of the 20th century have relied heavily on indigenous police as well as military forces(Corum 2006). Overall, Police needs to be provided with mandatory proper training and lead coordinating role in all levels of risk response, as they have legal authority to act on behalf of the government in a range of situations.

Despite the pivotal role of Police and military forces, other factors are also known to play a role in instigating terrorism that could affect tourism tremendously. Some of these factors are therefore discussed as follows.

\subsection{Role of Islamic Scholars}

Pakistan Prime Minister has called in religious scholars to play their role in eliminating extremism and terrorism by promoting tolerance (The New York Times, 2014).Al-Sakinah program in Saudi Arabia is a very good example of role of scholars in drawing extremists into debate and dialogue, while sharing their ideas with former Jihadist and Islamic scholars it is an opportunity for the extremist to understand and find a middle way between extremism and secularism(Gregg 2010). The government of Saudi Arabia supported the Al-Sakinah program to engage Jihadist online to educate them and convince them with dialogue to abandon their violent ideas and behaviour. Programs like this are beneficial for the public as well to understand the true meaning of Jihad and role of terrorism. It is allowed in Islam to have a difference of opinion but as mentioned in an authentic Hadith, the Lady Aisha said: 'Whenever faced by more than one choice, the Prophet (PBUH) always chose the easiest one (Narrated by Bukhari in Kitab al-Hudud, no. 6786), and in Quran '[Those] who listen to the words [of God] and follow the best [sense] of it. Those, they are the ones whom God has guided; and those, they are the people of pith.' (Al-Zumar, 39: 18). The government of Pakistan must engage 
the terrorists in arguments and justify why their ideas are wrong according to the law of Pakistan, human rights and as well as according to Quran. In the same context killing of prisoners is forbidden in Islam according to Quran '...Thereafter either [set them free] by grace or by ransom ...' (Muhammad, 47: 4). Another place in Quran it is commanded that captives and prisoners of war be treated with dignity and respect: 'And they give food, despite [their] love of it to the needy, and the orphan, and the prisoner.' (Al-Insan, 76: 8).

\subsection{Role of NATO Forces}

The role of NATO forces in fighting against terrorism has been always criticised by Pakistan. NATO forces have been trying to fight Taliban since 2001 and the result so far not to defeat Taliban but to push then across the border of Pakistan. The Taliban can move freely between Pakistan and Afghanistan and as the result, stabilized Afghanistan for the time being but destabilized Pakistan. Bruce Riedel, who served as Obama's top Afghanistan adviser during the 2008 presidential campaign, argued that NATO countries must "not let the global jihad take over Afghanistan and Pakistan and further expand their sanctuaries." For instance, in 2008 a huge suicide attack on Marriot Hotel badly damaged the building and 53 people killed and hundreds more injured. These attacks took place at a time when Pakistan was distress "over a wave of cross-border strikes on militant bases by U.S forces in Afghanistan" (Graham 2004). Pakistan's civil and military leadership had lodged a strong protest with their counterparts in Afghanistan and NATO, saying that their forces were doing nothing to check the activities of the insurgents, based in the Afghan provinces of Kunar and Nuristan. Afghanistan's Government was also not co-operating with Pakistan as the leader of Pakistan Taliban Mauliv Fazlullah and other militants were hiding in Afghanistan and were refused to hand them over. It is becoming a trend for Taliban now to give instructions on the phone from Afghanistan. Pakistan and Afghanistan have remained locked in a bilateral blame game, unwilling to understand that terror radicals understand neither borders nor national loyalties. Straight after Taliban attack on school children in Peshawar (December 2014), the chief of army staff and other top army officials met Afghanistan president and the senior NATO commanders to discuss military response, and according to news reports they agreed on doing a joint counter terrorism operation to eliminate the militants hiding in Afghanistan (Stars and Stripes, 2014).

\subsection{Pakistan Media}

Media plays a vital role in shaping individual image of destination specially in the time of crisis like terrorism or political instability. According to BBC Country Rating poll, (2011) Pakistan is the second negative image country, wherein media played a dominant role in forming that image. In 2007, Government of Pakistan tried to restrict media from showing the negative aspects of the country but with heavy protests and campaigns the journalists movement gained enough momentum to force the government reviewing the ban (The New York Times, 2012).The electronic media is a business and its primary motive is to earn money. Some countries in Middle East have restricted media to adjust what they apprehend to be negative. For instance, Israel issued complaints about American media owners on biased media coverage of events(Avraham 2013). The terrorists manipulate media, which then create fear amongst then tourists and general public(Sönmez, S., Apostolopoulos and Tarlow 1999). Al Qaida created fear with video messages to the world, which were shown on most of news channels. Now the trends are changing, and social media has provided a platform for terrorist, not just to share their murderous views but to recruit, for instance, the Islamic State (IS).The likelihood of online travellers to come across social media contents during web search process can be derived from The World Travel Market (WTM) Industry Report and Global Trends Report (2013) which notes 84\% of consumers trust word-of-mouth recommendations, or earned media, above all other forms of advertising.

\subsection{Domestic Tourism}

The impacts of terrorism on domestic tourist is much less damaging compared to the foreign tourist. For instance, the study from Yechiam et al described the impacts of Palestinian intifada (uprising) on Israeli hotels and behaviour of foreign and domestic tourists and found out that the domestic tourists are more resilient to such crisis, as the demand drop after any attack was $60 \%$ in foreign tourist compared to domestic ones, where only a reduction of $10 \%$ was seen (Yechiam, Barron, and Erev 2005). These finding suggests that tourism industry and the policy makers must not ignore the domestic tourists as they may yield faster results. Hence, Pakistan need to pay serious attention to 
facilitate own domestic tourism, as there is potential in the domestic tourism in the time of crisis due to their higher resilience to terrorism. However, poor tourism infrastructure and inflated cost of board and lodging, along with underprivileged standard of services at tourist spots, discourage domestic tourist as well. Director of Operations for Adventure Travel Pakistan (ATP), mentioned that it is a great challenge for Pakistan domestic market to revive tourism in Pakistan. It is the need of the hour to have promotional and awareness campaigns to rebuild our tourism industry. Additionally, former tourism minister Nilofar Bakhtiar mentioned there are various places in Pakistan which have the potential to become good tourist spots but it requires a proper government policy. Tourism experts says it is not just the fear of terrorism behind the declining tourism of Pakistan, ambiguous and antitourist policies are also affecting tourism of Pakistan (Dunya News, 2012). Additionally, NATO forces may have won its war against Al Qaeda but waging these terrorists and promoting a proxy war against Pakistan will make the condition worst for the world Khaled Ahmed (2009).Al-Qaida have been able to operate freely in Pakistan, acquire funds from states and non-state actors, access arms and munitions, acquire combat skills, move freely around the world and recruit openly for jihad (The Guardian, 2003). Security agencies have also found evidence of the collusion of some low-ranking police staff in the sectarian violence. Daily Times (2003) confirmed that few army officers below the rank of colonel as well as a few junior members of the military were found to have links with terrorists. The threat becomes more serious when some elements in security forces are sympathetic to the cause of terrorists. Even though the number of personnel involved in such activities is small, but the level of their involvement creates fear in the minds of people.

Overall, tourism officials should make certain that stakeholders such as judges, law enforcement officials, legislators, lawyers, and other government officials, as well as the tourism operational sectors are invited to participate in this systematic review. The objectives of which are to identify gaps in the laws or regulations and possible corrective measures for dealing with tourism safety and security issues. In some cases, the identified risk and its consequences are considered unacceptable for a destination.

\section{RECOMMENDATIONS}

An established tourism industry in Pakistan is not achievable without solving the dilemma of terrorism seeing that security is the most important concern of tourism. Therefore, Pakistan strategy makers will have to resolve the hurdle of terrorism first. People in Pakistan rely on religious books for obtaining religious information and their political view is also influenced by religious scholars. Even though several Islamic scholars from all schools of thought, condemn terrorism and religious radicalism, their view is not properly presented or publicized. It is important to repeat their message in media and explain to the young and misguided people of Pakistan and the terrorists as well, as they misinterpret Quran and recruit people. Religion remains a core element of people's belief system while lack of education and critical thinking guides and confuses the views of most of the people of jihad, extremism and radicalization. Terrorists in Pakistan are misguiding the innocent people of Pakistan by preaching them about Jihad, the role of scholars and the media is to explain the meaning of Jihad with reference to Quran and sayings of Prophet Muhammad (PBUH). Secondly, the strong relationship of Pakistan-China needs to build a partnership or provide common grounds for fighting terrorism. In this situation, where internal instability is the foremost strategic challenge and China is the most enduring strategic ally, there is a need for Pakistan to identify scope for collaboration with China to address the causes and the symptoms in the fight against terrorism. To formulate a winning antiterrorism strategy to win the war against terror, Pakistan need adequate resources and financial help. China is one of the few external sources from which Pakistan can expect more support. Thirdly, the role of media in fight against terrorism is very important. Media needs to highlight atrocities committed by terrorists and publish interviews of those who have returned from the extremist groups. The electronic media television and radio will have a significant role to play in the same. Independent electronic media can demonstrate better performance to provide good quality information with its wider reach. Unfortunately, Pakistan's several news channels are in constant competition to provide exclusive and sensational news, which can be controversial regarding terrorism and can lead the youth of Pakistan astray. Government of Pakistan need to provide direction to the media in the form of a national strategy, policy or guidelines about terrorism. Another aspect is the involvement of religious schools (Madrassa) in Pakistan that are been used by terrorists for purposes other than teaching religion. It is immensely important to have an accurate record of these schools. Pakistan government 
should consider a proper supervision of the functioning of these religious schools as any other private or government school. Before issuing registration their supply of revenue should be determined. Restriction on intolerable speeches and such literature, it is important to teach religion, but some literature should be restricted to a certain age limit.

To fight terrorism, Pakistan government need to change its policy toward India and make peace with India. If Pakistan and India are in good terms, Pakistan can focus only on terrorism at the border of Afghanistan without any fear of rival India. As soon as the military leadership is reasonably convinced of the projection of long-term harmony with India, the force that is currently devoted to line of control with India can be devoted to extremist organizations. Lastly, Pakistan domestic tourism can haul the struggling tourist industry from becoming completely in active, Pakistan tourism market rather than advertising to the international market should focus on its domestic market.

\section{REFERENCES}

[1] Adnan Hye, Qazi Muhammad and Rana Ejaz Ali Khan. 2013. "Tourism-Led Growth Hypothesis: A Case Study of Pakistan." Asia Pacific Journal of Tourism Research 18(4):303-13. Retrieved (http://www.tandfonline.com/doi/abs/10.1080/10941665.2012.658412).

[2] Aschauer, Wolfgang. 2010. "Perceptions of Tourists at Risky Destinations. A Model of Psychological Influence Factors." Tourism Review 65(2):4-20. Retrieved (http://www.emeraldinsight.com/doi/10.1108/16605371011061589).

[3] Avraham, Eli. 2013. "Crisis Communication, Image Restoration, and Battling Stereotypes of Terror and Wars."American Behavioural Scientist 57(9):1350-67. Retrieved (http://journals.sagepub.com/doi/10.1177/0002764213487733).

[4] Cohen, G. L., J. Garcia, V. Purdie-Vaughns, N. Apfel, and P. Brzustoski. 2009. "Recursive Processes in Self-Affirmation: Intervening to Close the Minority Achievement Gap." Science 324(5925):400-403. Retrieved (http://www.sciencemag.org/cgi/doi/10.1126/science.1170769).

[5] Cohen, Scott A., Girish Prayag, and Miguel Moital. 2014. "Consumer Behaviour in Tourism: Concepts, Influences and Opportunities." Current Issues in Tourism 17(10):872-909. Retrieved (http://www.tandfonline.com/doi/abs/10.1080/13683500.2013.850064).

[6] Corum, James Sterling. 2006. Training Indigenous Forces in Counterinsurgency: A Tale of Two Insurgencies. Strategic Studies Institute, U.S. Army War College.

[7] Davidson, Janine. 2009. "Principles of Modern American Counterinsurgency: Evolution and Debate." Brookings Institution. Retrieved (http://www.brookings.edu/ /media/Files/rc/ papers/2009/0608_counterinsurgency_davidson/0608_counterinsurgency_davidson.pdf).

[8] Dean, Abraham Pizam. 2002. “Tourism and Terrorism." International Journal of Hospitality Management 21(1):1-3. Retrieved (http://linkinghub.elsevier.com/retrieve/pii/S0278431901000378).

[9] Faulkner, Bill. 2001. "Towards a Framework for Tourism Disaster Management." Tourism Management 22(2):135-47. Retrieved (http://linkinghub.elsevier.com/retrieve/pii/S0261517700000480).

[10] Graham, Stephen, ed. 2004. Cities, War, and Terrorism. Malden, MA, USA: Blackwell Publishing. Retrieved (http://doi.wiley.com/10.1002/9780470753033).

[11] Gregg, HS. 2010. "Fighting the Jihad of the Pen: Countering Revolutionary Islam's Ideology." Terrorism and Political Violence 22(2):292-314.

[12] Henderson, J., C. Shufen, L. Huifen, and L. L. Xiang. 2010. "Tourism and Terrorism: A Hotel Industry Perspective." Journal of Tourism, Hospitality \& Culinary Arts 2:33-46.

[13] Henderson, Vernon. 2003. "The Urbanization Process and Economic Growth: The So-What Question." Journal of Economic Growth 8(1):47-71.

[14] Holloway, J.Christopher and Neil Taylor. 2006. The Business of Tourism. Pearson Education.

[15] Kapuściński, Grzegorz and Barry Richards. 2016. "News Framing Effects on Destination Risk Perception." Tourism Management 57:234-44. Retrieved (http://linkinghub.elsevier.com/retrieve/pii/S0261517716301030).

[16] Kozak, Metin, John C. Crotts, and Rob Law. 2007. "The Impact of the Perception of Risk on International Travellers." International Journal of Tourism Research 9(4):233-42. Retrieved (http://doi.wiley.com/10.1002/jtr.607).

[17] Lindberg, Frank, Ann Heidi Hansen, and Dorthe Eide. 2014. "A Multirelational Approach for Understanding Consumer Experiences within Tourism." Journal of Hospitality Marketing \& Management 23(5):487-512. Retrieved (http://www.tandfonline.com/doi/abs/10.1080/19368623.2013.827609).

[18] Pizam, Abraham and Aliza Fleischer. 2002. "Severity versus Frequency of Acts of Terrorism: Which Has a Larger Impact on Tourism Demand?" Journal of Travel Research 40(3):337-39. Retrieved (http://journals.sagepub.com/doi/10.1177/0047287502040003011). 
[19] Richter, L. 1999. "After Political Turmoil: The Lessons of Rebuilding Tourism in Three Asian Countries.” Journal ofTravel Research 38(1):41-45.

[20] Seddighi, H. R., A. L. Theocharous, and M. W. Nuttall. 2002. "Political Instability and Tourism." International Journal of Hospitality \& Tourism Administration 3(1):61-84. Retrieved (http://www.tandfonline.com/doi/abs/10.1300/J149v03n01_04).

[21] Shaw, Duncan, Matthew Hall, John S. Edwards, and Brad Baker. 2007. "Responding to Crisis through Strategic Knowledge Management" edited by P. Gleadle. Journal of Organizational Change Management 20(4):559-78. Retrieved (http://www.emeraldinsight.com/doi/10.1108/09534810710760081).

[22] Sönmez, S., Apostolopoulos, Y. and P. Tarlow. 1999. "Tourism in Crisis: Managing the Effects of Terrorism.” Journal of Travel Research 38(1):13-18.

[23] Sönmez, Sevil F. and Alan R. Graefe. 1998. "Influence of Terrorism Risk on Foreign Tourism Decisions." Annals of Tourism Research 25(1):112-44. Retrieved (http://linkinghub.elsevier.com/retrieve/pii/S0160738397000728).

[24] Thomas, Paul. 2012. Responding to the Threat of Violent Extremism: Failing to Prevent. Bloomsbury Publishing.

[25] Tichy, N. and W. Bennis. 2007. "Making Judgement Calls: The Ultimate Act of Leadership." Harvard Business Review 85(10):94-102.

[26] Wahab, Salah E. A. 1996. “Tourism Development in Egypt: Competitive Strategies and Implications.” Progress in Tourism and Hospitality Research 2(3-4):351-64. Retrieved (http://doi.wiley.com/10.1002/pth.6070020315).

[27] Yechiam, Eldad, Greg Barron, and Ido Erev. 2005. "The Role of Personal Experience in Contributing to Different Patterns of Response to Rare Terrorist Attacks.” Journal of Conflict Resolution49 (3):430-39. Retrieved (http://journals.sagepub.com/doi/10.1177/0022002704270847).

Citation: Muhammad Fahad Khan. "Review of the Recovery Strategies of Pakistan: Dealing Tourism Wreaked with Terrorism". International Journal of Research in Tourism and Hospitality (IJRTH), vol 4, no. 1, 2018, pp. 57-63. doi:http://dx.doi.org/10.20431/2455-0043.0401007.

Copyright: (C) 2018 Authors. This is an open-access article distributed under the terms of the Creative Commons Attribution License, which permits unrestricted use, distribution, and reproduction in any medium, provided the original author and source are credited. 